\title{
Rhodopseudomonas blastica sp.nov.: a Member of the Rhodospirillaceae
}

\author{
By KEVIN ECKERSLEY AND CRAWFORD S. DOW* \\ Department of Biological Sciences, University of Warwick, Coventry CV4 $7 A L$
}

(Received 6 December 1979; revised 23 February 1980)

\begin{abstract}
Inoculation of samples from a small eutrophic pond into pyruvate/malate medium at neutral $\mathrm{pH}$ yielded a new species of the Rhodospirillaceae described here as Rhodopseudomonas blastica. The cells are ovoid to rod-shaped, 1 to $2.5 \mu \mathrm{m}$ long and 0.6 to $0.8 \mu \mathrm{m}$ wide, non-motile and multiply by a process of sessile budding. The photosynthetic membrane system consists of lamellae parallel to and underlying the cell membrane. The photopigments consist of bacteriochlorophyll $a$ and carotenoids of the spheroidene group. Cells can grow anaerobically in the light using a wide range of organic compounds. Aerobic growth in the dark is also possible. Nicotinic acid and thiamin are required as growth factors. Good photolithotrophic growth with $\mathrm{H}_{2}$ is possible, but sulphide and thiosulphate cannot be used as electron donors. As this species has properties lying between the two groups of existing Rhodopseudomonas species, i.e. those which show intercalary growth and those which multiply by budding (asymmetric polar growth), a new species is hereby proposed.
\end{abstract}

\section{INTRODUCTION}

Eutrophic freshwater systems are a rich source of phototrophic bacteria, particularly those belonging to the genus Rhodopseudomonas (Siefert et al., 1978). Species within this genus exhibit such a morphological and ultrastructural diversity that it has been suggested that the genus be re-classified into two or three new groups (Gorlenko et al., 1976; Pfennig, 1977) (Table 1).

From samples of a small eutrophic freshwater pond, a phototrophic bacterium was isolated by enrichment on pyruvate/malate medium at neutral $\mathrm{pH}$. While characteristic of the genus Rhodopseudomonas, this organism was distinct from any one of the known species. It is described here as a new species of the Rhodospirillaceae: Rhodopseudomonas blastica.

\section{METHODS}

Source of organism. The organism was isolated from a small eutrophic freshwater pond on the campus of Warwick University.

Media. The mineral base used in all media contained (per litre distilled water): $\mathrm{NH}_{4} \mathrm{Cl}, 0 \cdot 5 \mathrm{~g} ; \mathrm{MgSO}_{4} \cdot 7 \mathrm{H}_{2} \mathrm{O}$,

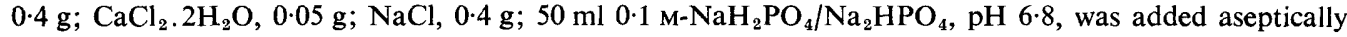
after autoclaving. The defined medium used routinely contained (per litre mineral base): sodium pyruvate, $1.5 \mathrm{~g}$; sodium hydrogen malate, $1.5 \mathrm{~g}$; thiamin. $\mathrm{HCl}, 0.02 \mathrm{mg}$; biotin, $0.02 \mathrm{mg}$; nicotinic acid, $0.1 \mathrm{mg}$; trace elements (Pfennig \& Lippert, 1966) $1 \mathrm{ml}$; the $\mathrm{pH}$ was adjusted to 6.8 with $\mathrm{KOH}$ prior to autoclaving. Complex medium contained in addition $0.1 \%(\mathrm{w} / \mathrm{v})$ yeast extract. In the enrichment medium, $0.1 \%(\mathrm{w} / \mathrm{v})$ yeast extract replaced the vitamins and trace elements solution of the defined medium; in addition, $\mathrm{MgSO}_{4}$ was omitted. When solid medium was required, agar was added to $1.5 \%(\mathrm{w} / \mathrm{v})$.

Enrichment and isolation. Enrichments were performed in screw-capped McCartney bottles completely filled with complex medium, incubated at $30^{\circ} \mathrm{C}$ with an incident light intensity of $2000 \mathrm{~lx}$ from tungsten 
Table 1. Proposed grouping of the current species of the genus Rhodopseudomonas (after Pfennig, 1977)

Species group

Species

Major morphological characteristics - cell shape

Arrangement of intracytoplasmic membrane system
1

2

3

R. capsulata

$R$. sphaeroides

$R$. globiformis

R. sulfidophila

Spherical to ovoid cells showing intercalary growth

Vesicular

Single small tubular or lamellar intrusions of cell membrane

\section{R. gelatinosa}

Slender rod-shaped to spirilloid cells showing intercalary growth lamps. Isolation and purification was achieved by serial dilution and repeat restreaking on to complex agar medium which was incubated under phototrophic conditions at $30^{\circ} \mathrm{C}$ with an incident light intensity of 2000 lx by the method of Westmacott \& Primrose (1975) as modified by Dow \& France (1980).

Growth conditions. Pure cultures of $R$. blastica were grown in $250 \mathrm{ml}$ Erlenmeyer flasks containing $100 \mathrm{ml}$ medium which were sealed with rubber serum caps (William Freeman \& Co., Barnsley, Yorkshire), flushed with $\mathrm{O}_{2}$-free $\mathrm{N}_{2}$ and incubated, with shaking, at $30^{\circ} \mathrm{C}$ under constant illumination (2000 lx). Chemoheterotrophic growth under aerobic conditions in the dark at $30^{\circ} \mathrm{C}$ was examined using complex medium.

Substrate utilization. Substrate utilization was examined using mineral base supplemented with growth factors, $\mathrm{NaHCO}_{3}(0.05 \%, \mathrm{w} / \mathrm{v})$ and the test substrate $(0.15 \%, \mathrm{w} / \mathrm{v})$, the $\mathrm{pH}$ being adjusted to 6.8 . However, utilization of methanol and ethanol were also examined at $\mathrm{pH} 7.5$ since it has been reported that growth of certain Rhodospirillaceae on these substrates is pH-sensitive (Quayle \& Pfennig, 1975).

The capacity for photolithotrophic growth was determined using the above medium to which thiosulphate or sulphide (sodium salts) was added. The latter experiments were repeated replacing the growth factors with yeast extract $(0.01 \%, \mathrm{w} / \mathrm{v})$ as this has been shown to increase sulphide tolerance in other members of the Rhodospirillaceae (Hansen \& van Gemerden, 1972). To examine the capacity for photolithotrophic growth with $\mathrm{CO}_{2}$ and $\mathrm{H}_{2}$, these were used at 20 and $80 \%(\mathrm{v} / \mathrm{v})$, respectively.

Utilization of nitrogen sources was investigated using defined medium from which $\mathrm{NH}_{4} \mathrm{Cl}$ was excluded. The test substrate was added at $0.05 \%(\mathrm{w} / \mathrm{v})$ and the flasks made anaerobic by flushing with Ar. Nitrogenase assays, using whole cells grown under $\mathrm{N}_{2}$ in defined medium lacking $\mathrm{NH}_{4} \mathrm{Cl}$, were performed as described by Zumft \& Castillo (1978).

In all experiments growth was measured turbidimetrically at $540 \mathrm{~nm}$.

Photopigments. The absorption spectrum was recorded for photosynthetically grown cells which had been centrifuged, washed and resuspended in $60 \%(\mathrm{w} / \mathrm{v})$ sucrose. Carotenoids from cells in the early-stationary growth phase were extracted according to the procedure of Schmidt (1971) and separated by thin-layer chromatography (t.I.c.) on silica gel F, using ethyl acetate/petroleum ether (b.p. 60 to $\left.80^{\circ} \mathrm{C}\right)(1: 10$, v/v) as solvent.

$D N A$ isolation and purification. Late-exponential growth phase cultures were harvested by centrifuging ( $20000 \mathrm{~g}$ for $30 \mathrm{~min})$ and washed in TES buffer $(0 \cdot 1 \mathrm{M}-\mathrm{NaCl} / 0 \cdot 05 \mathrm{M}$-Tris/0.001 $\mathrm{M}$-EDTA, adjusted to $\mathrm{pH} 7 \cdot 2$ with $\mathrm{HCl})$. Freshly prepared lysozyme $\left(1 \mathrm{mg} \mathrm{ml}^{-1}\right)$ was added and the cells were incubated at $37^{\circ} \mathrm{C}$ for $1 \mathrm{~h}$. Sodium lauryl sarcosinate was added at $2 \%(\mathrm{w} / \mathrm{v})$ to bring about lysis. DNA was isolated by centrifuging the lysate at $120000 \mathrm{~g}$ for $36 \mathrm{~h}$ in a linear $\mathrm{CsCl}$ gradient of mean density $1.71 \mathrm{~g} \mathrm{~cm}^{-3}$. Fractions were collected and dialysed for $15 \mathrm{~h}$ at $4{ }^{\circ} \mathrm{C}$ against standard saline citrate $(0.15 \mathrm{M}-\mathrm{NaCl} / 0.015 \mathrm{M}$-sodium citrate, $\mathrm{pH}$ adjusted to 7.0). Sample purity was determined by reading $A_{280} / A_{260}$ and the DNA concentration was calculated from the absorption coefficient.

DNA base composition. The buoyant density in neutral $\mathrm{CsCl}$ of the isolated DNA was determined using a Beckman model E Analytical Ultracentrifuge, operating at $140000 \mathrm{~g}$ and $25^{\circ} \mathrm{C}$ for a minimum of $22 \mathrm{~h}$. A cell with a $12 \mathrm{~mm} 4^{\circ} \mathrm{Kel} \mathrm{F}$ centre piece was used and photographs were taken using ultraviolet absorption optics. Films were examined with a Joyce-Loebl recording microdensitometer. DNA from Escherichia coli $\left(\rho=1.7100 \mathrm{~g} \mathrm{~cm}^{-3}\right.$ ) was used as a marker and the buoyant density and mol $\% \mathrm{G}+\mathrm{C}$ were calculated by the method of Mandel et al. (1968). 


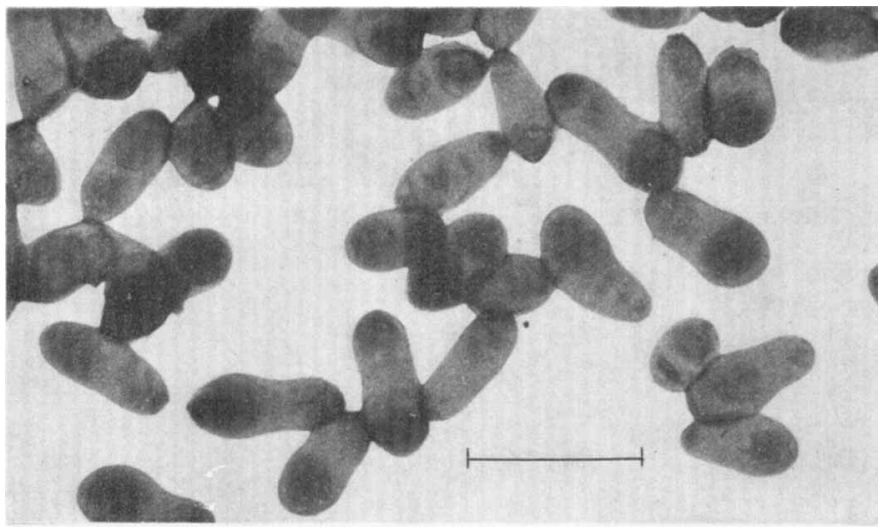

Fig. 1. Electron micrograph of $R$. blastica grown phototrophically on defined medium. Uranyl acetate stain. Bar marker represents $2 \mu \mathrm{m}$.

Slide culture and light microscopy. Anaerobic slide cultures were as described by Dow \& France (1980). Photomicrographs were obtained from an Olympus EHT microscope fitted with an Olympus PM-6 camera unit using Kodak Panatomic X film.

Electron microscopy. The fixation procedure of Ryter \& Kellenberger (1958) was followed for ultrathin sections which were cut on a Reichert OMU2 ultramicrotome. Micrographs were taken with a Jeol JEM $100 \mathrm{~S}$ instrument operating at $60 \mathrm{kV}$.

\section{RESULTS}

Enrichment and isolation

Mineral medium of neutral $\mathrm{pH}$, lacking $\mathrm{MgSO}_{4}$ and supplemented with pyruvate, malate and yeast extract, offers selective enrichment conditions for the Rhodospirillaceae. When such medium was inoculated with surface mud samples from a small eutrophic pond and incubated anaerobically under constant illumination one of two species became dominant: either a strain of Rhodopseudomonas palustris was found or, less frequently, enrichments became orange-brown in colour and were found to contain cells morphologically distinct from all documented species of Rhodospirillaceae. The latter was obtained in pure culture and maintained on complex medium.

\section{Morphology and ultrastructure}

The cells of this new species were short Gram-negative rods which immediately after cell division were spherical to ovoid (Fig. 1). Cells grown on complex medium were 0.6 to $0.7 \mu \mathrm{m}$ wide and 1.0 to $2.5 \mu \mathrm{m}$ long. Little variation of cell dimensions with growth medium composition was observed although in media containing yeast extract there was a tendency to form abnormally swollen cells and spheroplasts. Similar observations have been made with strains of Rhodopseudomonas capsulata (Weaver et al., 1975). Cell growth occurred by budding (asymmetric polar growth); however, no tube or filament was formed between the cells and division occurred by binary fission when both cells were of equal size. Growth thereafter continued at the newly formed poles (Fig. 2). Although cells at division appeared morphologically similar they differed with regard to the time taken to reach the next division, i.e. the mother cell initiated cell growth immediately after division whereas the daughter cell had to undergo an obligate period of maturation (Fig. 2). Cells did not form chains nor did they form rosettes characteristic of cells possessing polar 'holdfast' material (Whittenbury \& McLee, 1967). Motility was not observed under any growth conditions.

Ultrathin sections of photosynthetically grown cells revealed an intracytoplasmic system consisting of membranes parallel to and underlying the cytoplasmic membrane (Fig. 3). 


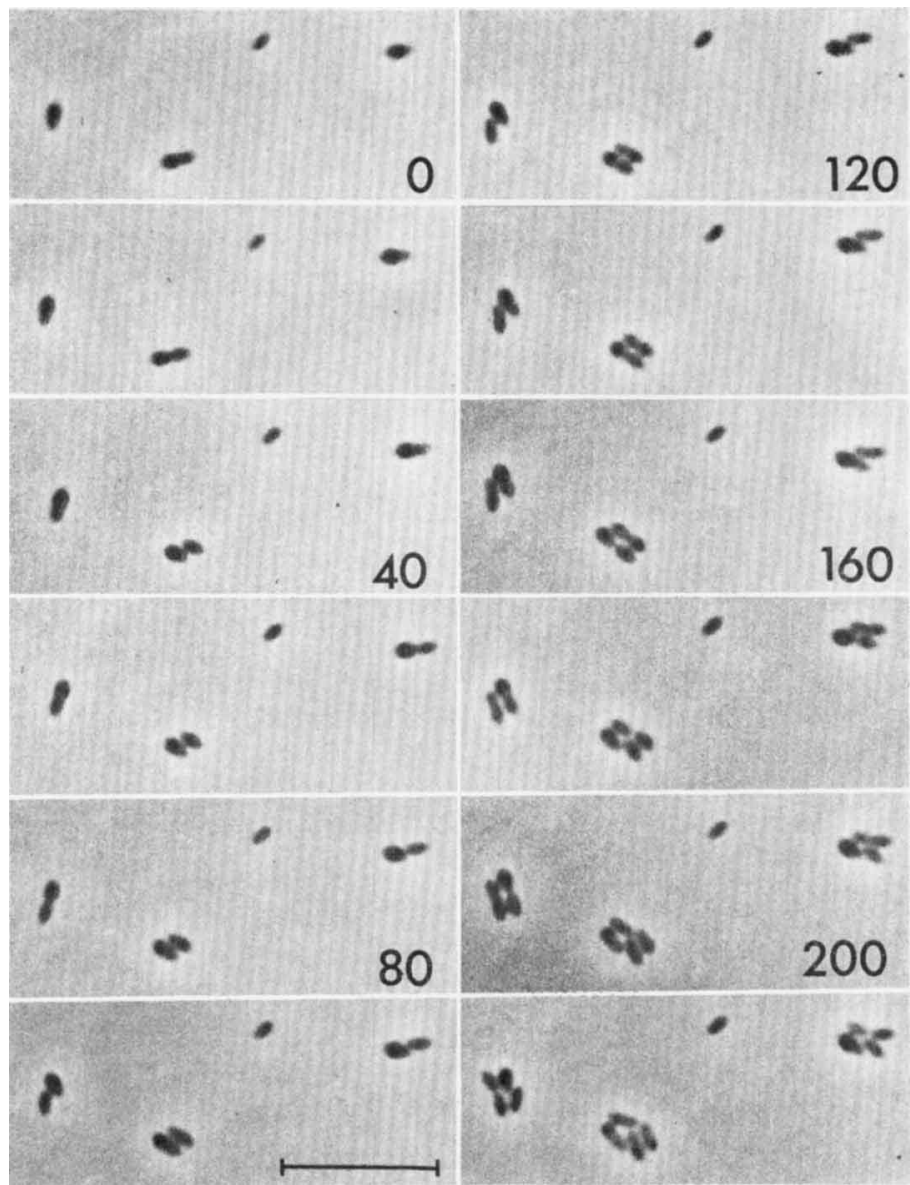

Fig. 2. Sequential phase contrast photomicrographs of $R$. blastica grown phototrophically on complex medium. Photographs were taken at 20 min intervals. Bar marker represents $10 \mu \mathrm{m}$.

These studies also suggested that the membrane system was formed de novo in the daughter cell.

\section{Photopigments}

Cultures grown phototrophically with pyruvate and malate as substrates were orangebrown. No colour change was observed when such cultures were shaken in air. Aerobically grown cultures were white to faint pink.

The absorption spectrum of whole cells (Fig. 4) showed the absorption maxima characteristic of bacteriochlorophyll $a(378,590,795$ and $862 \mathrm{~nm})$ with carotenoid absorption maxima at 418,476 and $506 \mathrm{~nm}$.

A preliminary study of the extracted photopigments using t.1.c. indicated the presence of carotenoids of the spheroidene group (Liaaen-Jensen, 1963). Such extracts were compared with those from $R$. capsulata NCIB 8254, $R$. sphaeroides NCIB 8253 and $R$. gelatinosa NCIB 8290 (Fig. 5).

\section{Physiology}

The vitamins required for growth were nicotinic acid and thiamin. Biotin gave considerable growth stimulation. Addition of all three to the growth medium, however, did not achieve the same growth rate as the inclusion of $0.1 \%(w / v)$ yeast extract.

A wide range of compounds supported photo-organotrophic growth (Table 2). Methanol 


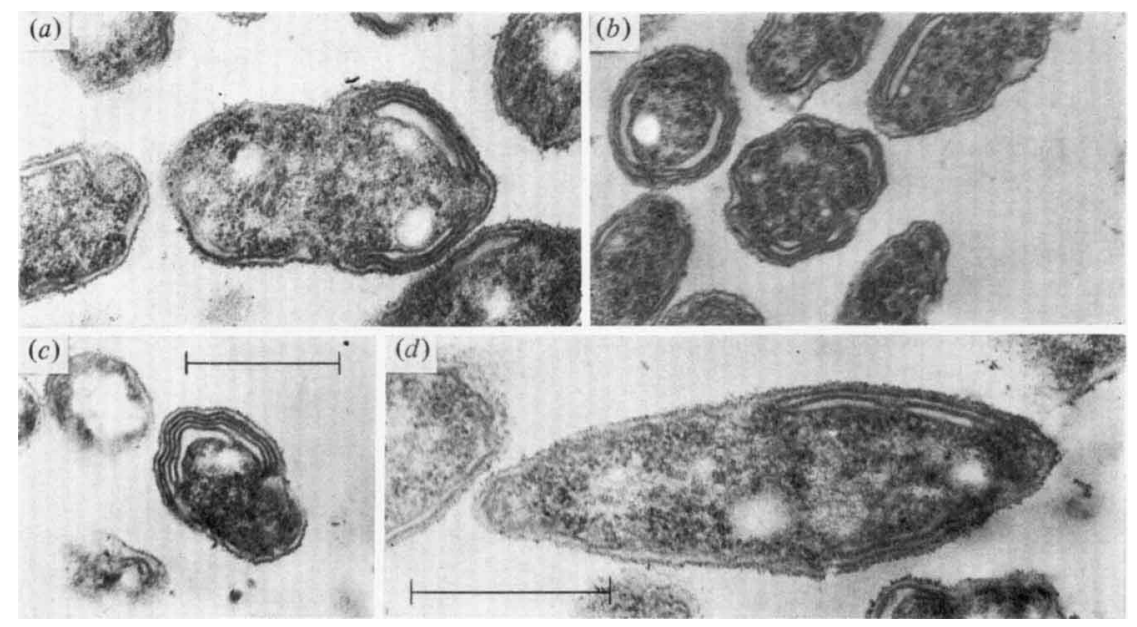

Fig. 3. Ultrathin longitudinal $(a, c, d)$ and transverse $(b)$ sections of $R$. blastica grown phototrophically on defined medium at $30^{\circ} \mathrm{C}$ with an incident light intensity of $2000 \mathrm{~lx}$. Bar markers represent $0.5 \mu \mathrm{m}$ (marker in $c$ refers to $a, b$ and $c$ ).

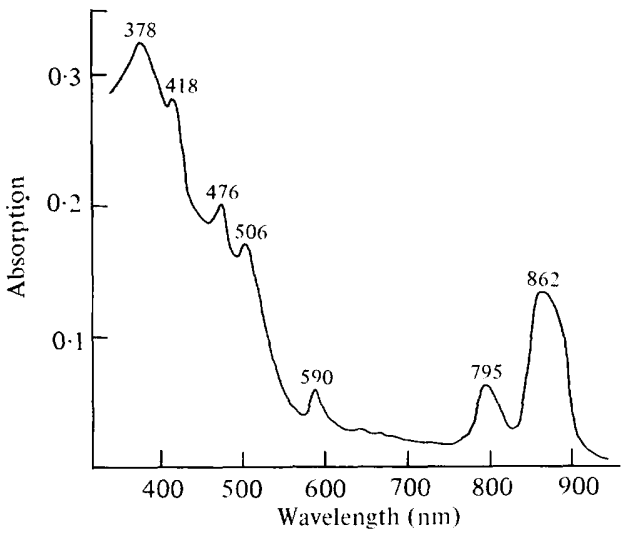

Fig. 4

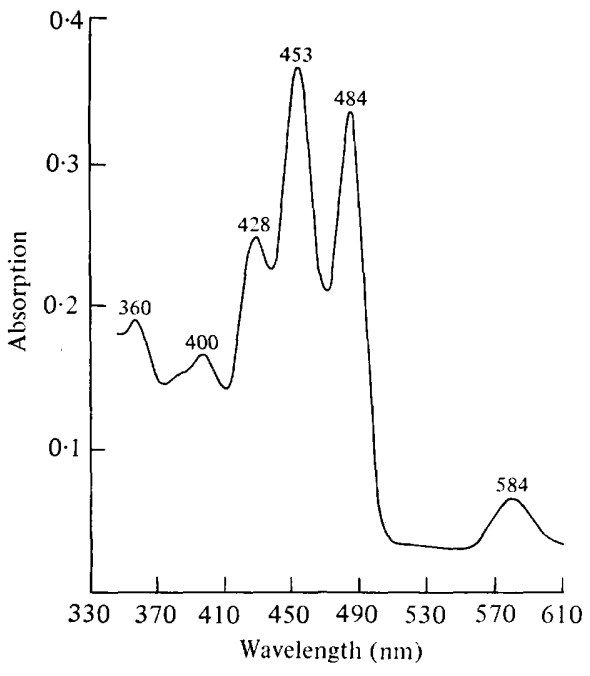

Fig. 5

Fig. 4. Absorption spectrum of whole cells of $R$. blastica grown phototrophically on defined medium at $30^{\circ} \mathrm{C}$ with an incident light intensity of $2000 \mathrm{~lx}$. Cells were suspended in $60 \%(\mathrm{w} / \mathrm{v})$ sucrose. The peaks at $378,590,795$ and $862 \mathrm{~nm}$ are characteristic of the bacteriochlorophyll and those at 418,476 and $506 \mathrm{~nm}$ of the carotenoids.

Fig. 5. Absorption spectrum of extracted photopigments from $R$. blastica. Those of $R$. capsulata NCIB 8254, $R$. sphaeroides NCIB 8253 and $R$. gelatinosa NCIB 8290 were identical. The solvent was petroleum ether (b.p. 60 to $80^{\circ} \mathrm{C}$ ).

or ethanol were not utilized, irrespective of the $\mathrm{pH} . \mathrm{H}_{2}$ and $\mathrm{CO}_{2}$ supported photolithotrophic growth, but sulphide and thiosulphate would not serve as electron donors.

Good aerobic, chemoheterotrophic growth on complex medium was possible in the dark at high oxygen tensions, both in liquid media and on agar plates, and was sustained in liquid media for several subcultures before the cells showed any tendency towards pleiomorphy. Attempts to grow the organism under strict anaerobic conditions in the dark, providing pyruvate and malate as substrates, were unsuccessful. Slow fermentation of these 
Table 2. Utilization of electron donors and organic compounds for phototrophic growth by $R$. blastica

For comparison, results for $R$. sulfoviridis (Keppen \& Gorlenko, 1975) and $R$. sphaeroides (Van Niel, 1944) are included.

\begin{tabular}{|c|c|c|c|}
\hline Substrate & R. blastica* & R. sulfoviridis $\dagger$ & R. sphaeroides $\dagger$ \\
\hline Pyruvate & 3 & _- & + \\
\hline Citrate & 1 & - & + \\
\hline Succinate & 3 & + & + \\
\hline Fumarate & 3 & + & + \\
\hline Malate & 3 & + & + \\
\hline Acetate & 3 & + & + \\
\hline Butyrate & 2 & + & + \\
\hline Lactate & 2 & + & NT \\
\hline Formate & 0 & - & NT \\
\hline Propionate & 2 & - & - \\
\hline Tartrate & 0 & - & + \\
\hline Glycerol & 2 & + & + \\
\hline Glycollate & 0 & NT & NT \\
\hline Benzoate & 0 & - & NT \\
\hline Glutamate & 2 & NT & NT \\
\hline Methanol & 0 & - & NT \\
\hline Ethanol & 0 & + & + \\
\hline Ribose & 2 & NT & NT \\
\hline Glucose & 3 & + & + \\
\hline Fructose & 3 & + & + \\
\hline Mannitol & 2 & - & + \\
\hline Sorbitol & 3 & + & + \\
\hline Hydrogen & 2 & NT & + \\
\hline Sulphide & 0 & + & - \\
\hline Thiosulphate & 0 & + & - \\
\hline Casamino acids & 3 & NT & NT \\
\hline Yeast extract & 3 & NT & + \\
\hline
\end{tabular}

compounds under such conditions by some Rhodopseudomonas species has been reported (Uffen \& Wolfe, 1970).

The optimal $\mathrm{pH}$ range for growth on pyruvate/malate medium was 6.5 to $7 \cdot 5$, and the optimal temperature range 30 to $35^{\circ} \mathrm{C}$.

Ammonium salts were the best nitrogen sources for growth, although a wide range of simple and complex organic nitrogen compounds could be utilized. Those utilized were glutamate, glutamine, aspartate, alanine, ornithine, tyrosine, thymine and urea. Nitrite and nitrate were not utilized. As is typical among purple bacteria, $\mathrm{N}_{2}$ could serve as a sole nitrogen source. Cells could be grown and repeatedly subcultured in media in which the only nitrogen source was $\mathrm{N}_{2}$. Cells grown under such conditions had an active nitrogenase as judged by the acetylene reduction assay. The highest rate of acetylene reduction obtained was $2 \mathrm{nmol}$ (mg protein) ${ }^{-1} \mathrm{~min}^{-1}$; this is a low rate compared with those for other Rhodopseudomonas species (Meyer et al., 1978).

The mol $\% \mathrm{G}+\mathrm{C}$, as determined by buoyant density, was $65 \cdot 3 \%$.

\section{DISCUSSION}

Under all growth conditions Rhodopseudomonas blastica reproduced by asymmetric polar growth, a feature characteristic of the members of species group 3 (Table 1). Its relatedness 
to this group was strengthened as it possessed an intracytoplasmic membrane system of the lamellar type, which also provides additional evidence to support the proposal by Whittenbury \& McLee (1967) that a correlation exists between this type of membrane system and a budding mode of growth.

Associated with a budding mode of growth, cells produced at division are morphologically and physiologically distinct from one another, i.e. most budding bacteria, including the Rhodopseudomonas species of group 3, possess dimorphic life cycles (Whittenbury \& Dow, 1977). In these organisms division is asymmetric giving rise to a non-motile mother cell and a motile daughter cell which differ in that the mother cell is capable of reproduction immediately after division whereas the daughter cell must undergo an obligate period of maturation. Budding in $R$. blastica is sessile, i.e. no tube or filament is formed between the mother and daughter cell, and in this respect it resembles $R$. acidophila (Pfennig, 1969) and $R$. sulfoviridis (Keppen \& Gorlenko, 1975). However, at division $R$. blastica produces two identical cells indicating division to be symmetrical. Evidence that the cell cycle of $R$. blastica is, in fact, dimorphic has come from slide culture studies (Fig. 2). Although division is symmetrical, the daughter cell does not divide until after division has been accomplished by the mother cell, which suggests that, before it is reproductively competent, the daughter cell must pass through a phase of maturation - possibly de novo synthesis of the photosynthetic membrane system, as there are no obvious external morphological changes.

Rhodopseudomonas blastica and Rhodocyclus purpureus (Pfennig \& Trüper, 1973) are the only species of Rhodospirillaceae in which motility has not been observed. In several Rhodopseudomonas species, motility has been reported to have been lost with changes in cultural conditions, e.g. $R$. acidophila and $R$. palustris (Tauschel \& Hoeniger 1974) and $R$. sulfidophila (Hansen \& Veldkamp, 1973); R. blastica was non-motile under all conditions tested.

The species of groups 1 and 2 (Table 1), except for $R$. globiformis, possess carotenoids of the spheroidene group, the distribution of which seems to be restricted to these four species. It appears, however, that $R$. blastica possesses carotenoids of this type. Though it is characteristic for anaerobic cultures of organisms possessing these carotenoids to change colour from brown to red in the presence of $\mathrm{O}_{2}$, due to the formation of 2-oxycarotenoids, cultures of $R$. blastica did not show such a colour change. This may be due to the absence of the enzyme system responsible for the carotenoid oxidations (Schneour, 1962).

Physiologically, $R$. blastica possesses many properties characteristic of the Rhodospirillaceae, being able to utilize a wide spectrum of organic compounds. However, it is the ability to utilize monosaccharides which distinguishes it from the other budding Rhodopseudomonas species. The exception within the group 3 species is $R$. sulfoviridis (Keppen \& Gorlenko, 1975) which can utilize sugars and, like $R$. blastica, possesses a comparatively simple cell cycle. In many respects $R$. blastica resembles $R$. sulfoviridis. Both grow by sessile budding and possess a lamellar membrane system, they are of the same dimensions and their spectrum of utilizable carbon compounds shows close similarity. They differ in photopigments ( $R$. sulfoviridis possesses bacteriochlorophyll $b, R$. blastica bacteriochlorophyll $a$ ), in the ability to utilize sulphide, thiosulphate and pyruvate, and in motility $(R$. sulfoviridis is motile).

Morphologically and with respect to the mode of growth, $R$. blastica resembles the budding Rhodopseudomonas species of group 3. However, the simplicity of its cell cycle, its photopigments and its physiology suggests relatedness to group 1. Association with the latter has been strengthened by the observation that a bacteriophage isolated for $R$. blastica causes 'lysis from without' of $R$. sphaeroides NCIB 8253 (K. Eckersley \& C.S. Dow, unpublished results).

An overview of the properties of this isolate indicates that, while it possesses the general characteristics of the genus Rhodopseudomonas, it is distinct from the described species and should be accommodated by the creation of a new species. 


\section{Rhodopseudomonas blastica sp.nov.}

blast'ic.a. M.Gr. adj. blastikos apt to bud.

Cells are ovoid to rod-shaped, 1 to $2.5 \mu \mathrm{m}$ long and 0.6 to $0.8 \mu \mathrm{m}$ wide. Multiplication is by budding (asymmetric polar growth) without the production of a tube or filament between the mother and daughter cells. Division is symmetric, both cells being non-motile. Gramnegative.

The photosynthetic membrane consists of lamellae underlying and parallel with the cell membrane. The membrane system is formed de novo in the daughter cell.

Anaerobic liquid cultures are orange-brown, becoming dark brown. Aerobically grown cultures are white to pale pink. No colour change is observed on the admission of air into anaerobically grown cultures.

Photo-organotrophic, facultatively aerobic, growing either anaerobically in the light or aerobically in the dark. Optimal $\mathrm{pH}$ range, 6.5 to $7 \cdot 5$. Optimum temperature, 30 to $35^{\circ} \mathrm{C}$. Growth factors required are thiamin and nicotinic acid. Yeast extract and biotin stimulate growth appreciably.

A wide range of organic substrates are photoassimilated including most intermediates of the tricarboxylic acid cycle, sugars, sugar alcohols, several amino acids, lactate, glycerol and butyrate. Not utilized: alcohols, tartrate, formate and benzoate. Photolithotrophic growth using molecular hydrogen and carbon dioxide. Sulphide and thiosulphate cannot be used as electron donors.

Nitrogen sources: ammonium salts and amino acids; $\mathrm{N}_{2}$ can be fixed. Nitrate or nitrite are not utilized.

Photopigments: absorption spectra of whole cells show the maxima characteristic of bacteriochlorophyll $a(378,590,795$ and $862 \mathrm{~nm})$ and also carotenoid maxima at 418, 476 and $506 \mathrm{~nm}$.

Unable to liquefy gelatin. Catalase present.

DNA base composition: $65 \cdot 3 \mathrm{~mol} \% \mathrm{G}+\mathrm{C}$.

Source: small freshwater eutrophic pond.

Type strain: NCIB 11576.

K. Eckersley gratefully acknowledges the financial assistance of the Natural Environment Research Council (Research Studentship GT4/77/ALS/37).

\section{REFERENCES}

Dow, C.S. \& France, A. D. (1980). Simplified vegetative cell cycle of Rhodomicrobium vannielii. Journal of General Microbiology 117, 47-55.

Gorlenko, V. M., Keppen, O. I. \& Puchkov, A. N. (1976). Morphological differentiation in nonsulphur purple bacteria. Microbiology (English translation of Mikrobiologiya) 45, 705-710.

HANSEN, T. A. \& VAN Gemerden, H. (1972). Sulphide utilization by purple non-sulfur bacteria. Archiv für Mikrobiologie 86, 49-56.

HANSEN, T. A. \& VeldKAMP, H. (1973). Rhodopseudomonas sulfidophila, nov.spec., a new species of the purple non-sulfur bacteria. Archiv für Mikrobiologio 92, 45-58.

Keppen, O. I. \& Gorlenko, V. M. (1975). A new species of purple budding bacteria containing bacteriochlorophyll b. Microbiology (English translation of Mikrobiologiya) 44, 224-229.

LIAAEN-JENSEN, S. (1963). Carotenoids of photosynthetic bacteria - distribution, structure and biosynthesis. In Bacterial Photosynthesis, pp. 19-34. Edited by H. Gest, A. SanPietro \& L. P. Vernon. Yellow Springs, Ohio: Antioch Press.
Mandel, M., Schildkraut, C. L. \& Marmur, J. (1968). Use of $\mathrm{CsCl}$ density gradient centrifugation analysis for determining the guanine plus cytosine content of DNA. Methods in Enzymology 12B, 184-195.

Meyer, J., Kelley, B. C. \& Vignais, P. M. (1978). Aerobic nitrogen fixation by Rhodopseudomonas capsulata. FEBS Letters 85, 224-228.

PfenNig, N. (1969). Rhodopseudomonas acidophila, sp.n., a new species of the budding purple nonsulfur bacteria. Journal of Bacteriology 99, 597602.

PfENNig, N. (1977). Phototrophic green and purple bacteria: a comparative, systematic survey. Annual Review of Microbiology 31, 275-290.

PfenNig, N. \& Lippert, K. D. (1966). Über das Vitamin $\mathrm{B}_{12}$-Bedürfnis phototropher Schwefelbakterien. Archiv für Mikrobiologie 55, 258-266.

Pfennig, N. \& TrüPer, H. G. (1973). The Rhodospirillales (phototrophic or photosynthetic bacteria). In Handbook of Microbiology, vol. 1, pp. 17-27. Edited by A. I. Laskin \& H. A. Lechevalier. Cleveland: CRC Press. 
Quayle, J. R. \& Pfennig, N. (1975). Utilisation of methanol by Rhodospirillaceae. Archives of Microbiology 102, 193-198.

Ryter, A. \& Kellenberger, E. (1958). Étude au microscope électronique de plasmas contenant de l'acide désoxyribonucléique. I. Les nucléotides des bactéries en croissance active. Zeitschrift für Naturforschung 13b, 597-605.

SchmidT, K. (1971). Carotenoids of purple nonsulphur bacteria. Archiv für Mikrobiologie 77, 231-238.

Schneour, E. A. (1962). Carotenoid pigment conversion in Rhodopseudomonas spheroides. Biochimica et biophysica acta 62, 534-540.

Siefert, E., Irgens, R. L. \& Pfennig, N. (1978). Phototrophic purple and green bacteria in a sewage treatment plant. Applied and Environmental Microbiology 35, 38-44.

Tauschel, H. D. \& Hoeniger, J. F. M. (1974). The fine structure of Rhodopseudomonas acidophila. Canadian Journal of Microbiology 20, 13-17.

UfFEN, R. L. \& WOLFE, R. S. (1970). Anaerobic growth of purple non-sulfur bacteria under dark conditions. Journal of Bacteriology 104, 462-472.
VAN Niel, C. B. (1944). The culture, general physiology, morphology and classification of the non-sulfur purple and brown bacteria. Bacteriological Reviews 8, 1-118.

Weaver, P. F., Wall, J. D. \& Gest, H. (1975). Characterization of Rhodopseudomonas capsulata. Archives of Microbiology 105, 207-216.

Westmacott, D. \& Primrose, S. B. (1975). An anaerobic bag for photoheterotrophic growth of some Rhodospirillaceae in Petri dishes. Journal of Applied Bacteriology 38, 205-207.

Whittenbury, R. \& Dow, C. S. (1977). Morphogenesis and differentiation in Rhodomicrobium vannielii and other budding and prosthecate bacteria. Bacteriological Reviews 41, 754-808.

Whittenbury, R. \& McLeE, A. G. (1967). Rhodopseudomonas palustris and $R$. viridis - photosynthetic budding bacteria. Archiv für Mikrobiologie 59, 324-334.

Zumft, W. G. \& Castillo, F. (1978). Regulatory properties of the nitrogenase from Rhodopseudomonas palustris. Archives of Microbiology 117, 53-60. 